\title{
Intergradation of Different Fertilizers for Sustainable Agriculture Enhanced Growth and Yield of Wheat (Triticum aestivum L.)
}

\author{
Ibrahim El-Akhdar ${ }^{1}$, Alaa El-Dein Omara ${ }^{1^{*}}$ and Mohamed Ali Abdel-Rahman ${ }^{2}$ \\ ${ }^{1}$ Department of Agricultural Microbiology, Soil, Water and Environment Research \\ Institute, Agricultural Research Center, Giza, Egypt ${ }^{2}$ Botany and Microbiology \\ Department, Faculty of Science (Boys), Al-Azhar University, Cairo, Egypt.
}

\section{Graphical Abstract}

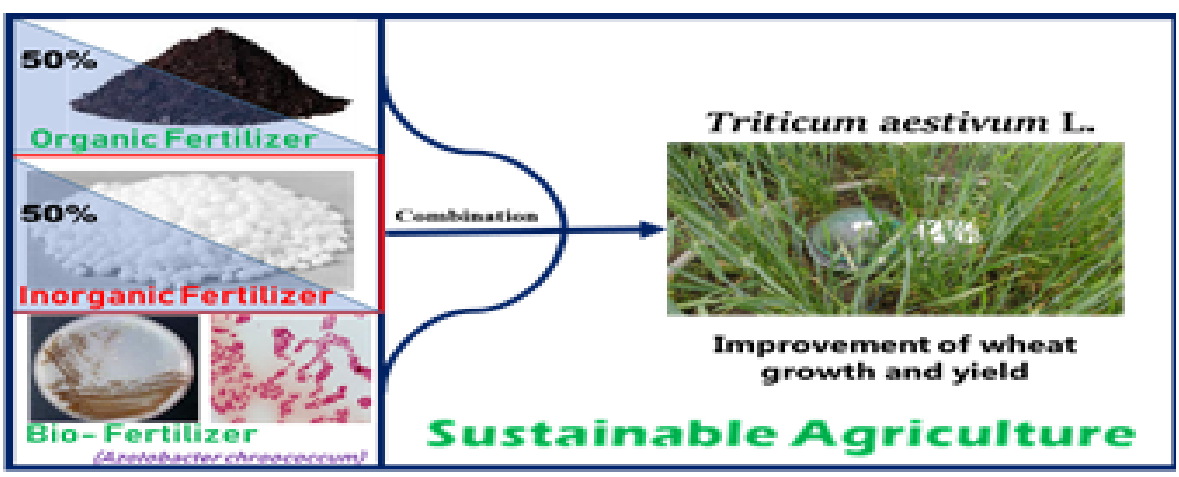

RGANIC farming is an advantageous agricultural system that enhances agro-ecosystem health, including biogeochemical cycles, biological activity and biodiversity in soils. In this regard, pots and lyzemeter experiments were conducted to evaluate eight compost preparations, and to investigate the combined effect of compost- Azotobacter chroococcum on growth and yield of wheat (Triticum aestivum L.) Cv. Misr 2 under different nitrogen levels (25, 50,75 and $100 \%$ of full dose of nitrogen fertilizer). In pot experiment, application of compost treatment No. 8 (produced by mixture of rice straw, cattle dung and inoculated with Bacillus licheniformis and Bacillus sonorensis) attained the highest vegetative growth parameters at 46.3 $\mathrm{cm}$ plant height, $8.92 \mathrm{~g}$ plant fresh weight and $2.96 \mathrm{~g}$ dry weight of wheat plants at 30 days after sowing comparing with control. On the other hand, results in lyzemeter experiment showed that treatment No. $9(50 \%$ of full dose of nitrogen fertilizer $+50 \%$ compost (pile 8$)+$ inoculation with $A$. chroococcum), is the most effective treatment for enhancing growth dynamics, enzyme activity and microbial populations. Also, the highest data of biological yield, grain yield and straw yield were recorded $22.5,8.64$, and 13.92 ton $\mathrm{ha}^{-1}$, compared to traditional $\mathrm{N}$-fertilizer, respectively. Therefore, this study could establish the successive uses of cellulase producing microbes, B. licheniformis and B. sonorensis, and $\mathrm{N}_{2}$-fixing bacteria A. chroococcum as friendly microorganisms to improve wheat production.

Keywords: Organic fertilizer; Bacillus licheniformis; Bacillus sonorensis; Azotobacter chroococcum; Wheat growth.

\section{Introduction}

In Egypt, wheat is the most important grain and is grown throughout the Delta region, along the branches of the Nile, as well as in the newly reclaimed areas. In 2012, wheat was grown on 4.3 million farms and it alone accounted for USD 3.7 billion, around $9 \%$ of the total value of agricultural production and over one-fifth $(22 \%)$ of the total value of field crops (USD 17.3 billion). Wheat has managed to increase its share of the winter cropped area from around 41 to $47 \%$. Egypt remains the world's largest wheat importer at about 12 million tonnes (www.fao.org/giews/ countrybrief/country.jsp? code=EGY).

*Corresponding author e-mail: alaa.omara@yahoo.com DOI: 10.21608/JENVBS.2018.3479.1025

C2017 National Information and Documentation Center (NIDOC) 
The macro and micro plant nutrients play an important role in the productivity of agricultural crops as well as for the environment (Tsai et al. 2007). Since, the advent of green revolution and high input agriculture practices, chemical fertilizer have become the major source of nitrogen for crop plants (Peoples et al. 1995), although continuous use of chemical fertilizers has led to the environmental pollution and contamination of the soil, pollution of water basins, and disruption of flora-fauna of ecosystem and ultimately reduced soil fertility (Mishra et al. 2013). Therefore, uses of organic and biofertilizers or bio inoculants in agriculture protect the environment as they are eco-friendly and economic for the farmers (Khosro and Yousef 2012). This should reduce the negative impact of chemical fertilizers with beneficial effect on the growth of plants and responsible for enhanced crop yield.

Rice straw is the most abundant lignocellulosic agro-residues in Egypt of about 3.1 million tons are produced annually (Abdelhady et al. 2014). These biomasses can be utilized for production of various value-added products via microbial fermentation processes (Abdel-Rahman et al. 2011; Sakdaronnarong and Jonglertjunya 2012; Abdel-Rahman et al. 2015). Composting is one of the useful methods that can directly consume large amount of wastes for compost production that can be used as a source of nutrients to improve soil structure, increase its organic matter, and enhance plant growth (Liu et al. 2011). The compost must be in a high degree of maturity and stability for safe application in agriculture without any adverse effects on plants (Qian et al. 2014). Inoculation of microbial additives that can tolerate composting condition, accelerate the composting process and increase nutrients have been used by several authors (Kausar et al. 2014; Abdel-Rahman et al. 2015; Jiang et al. 2015). Compost with beneficial microorganisms achieved higher available N,P,K, and $\mathrm{Fe}$ contents as compared to compost without microorganisms and increases the macro and micronutrient content of the soil.

The microbial activity has a huge importance in weathering and soil formation, through the mineralization and immobilization processes of nutrients. Therefore, the application of organic fertilizers (e.g. manure, crop residues or compost) has been practiced for a long time in order to increase the amount of microorganisms, soil fertility, soil quality and health, as well as enhancing the productivity, yield, and quality of crops (Cooperband and Wisconsin 2002; Mariangela and Francesco 2010). These microorganisms can release beneficial soluble substances such as amino acids, sugars, alcohol, hormones and similar organic compounds that can be easily absorbed by plants and can significantly increase the grain and biomass production (Ndona et al. 2011; Lindani and Brutsch 2012; Dehghani et al. 2013; Jusoh et al. 2013).

On the other hand, free living bacteria are highly beneficial for plant growth. They are collectively known as plant growth promoting rhizobacteria (PGPR) (Kloepper, 1994). These PGPRs are mainly involved in metabolic process related to nitrogen fixation, phosphate solubilization and overall plant growth promotion. Among those, the non-symbiotic free living Azotobacter and Azospirillum are largely associated with nitrogen fixation in plant rhizosphere and enhancement of plant yield (Lakshminarayana et al. 2000) which can have applied either as combined or as single inoculation which input of soil ranges from 0-60 $\mathrm{kg} \mathrm{ha}^{-1}$ year-1 $^{-1}$ (Bandhu and Parbati 2013). Maize and wheat crops inoculated with Azotobacter significantly showed increased plant height, grain weight and yield over the non-inoculated treatment (Barik and Goswami 2003). This is due to its capability of biological nitrogen fixation, synthesis of antibiotics, plant growth hormones production, vitamins production and plant hormones like indole acetic acid, gibberellins, and cytokinins (Gebrejewergs and Daniel 2016), exopolysaccharides and pigments (Jimenez et al. 2011). Therefore, the development of sustainable agricultural use of Azotobacter as biofertilizer has great importance to improve nutrient profile of plant and soil and increase crop yield accompanied by protection of environmental pollution and soil contamination (Namvar et al. 2012 and Rana et al. 2012).

Therefore, this studyaimsatsmartuse offriendly microorganisms to improve wheat production. Studying the effect of different compost materials prepared with/without inoculation of cellulase producing microbes, Bacillus licheniformis 1-1v and Bacillus sonorensis $7-1 \mathrm{v}$ on wheat growth will be investigated. Also, we will evaluate the effect of different fertilizers (organic, inorganic, and biofertilizer) either separately or in mixture on the growth parameters and yield of wheat plants (Triticum aestivum L.). 


\section{Materials and methods}

Compost piles

Eight compost piles (T1-T8) obtained from previous study by Abdel-Rahman et al. (2016) at Microbiology Department, Sakha Agricultural Research Station, Kafr El-Sheikh, Egypt were kindly provided to conduct this study. The composition of different composts is shown in Table 1, as well as their chemical and biological analysis are shown in Table 2.

\section{Grains used}

The used grains of Wheat (Triticum aestivum L.) C.V. Misr 2 were kindly supplied by Field Crops Research Institute, Sakha, Agricultural Research Station, Egypt.

Preparation of Azotobacter chroococcum culture Azotobacter chroococcum (SARS 10) strain was grown in 500-ml flask containing 250-ml using Jensen's liquid media at $30^{\circ} \mathrm{C}$. After 7 days of incubation, the number of cells $\mathrm{ml}^{-1}$ were determined using total viable count on plates conducted by Jensen (1951).

TABLE 1. Composition of composts used in pot experiment

\begin{tabular}{|c|c|}
\hline No. & Pile content \\
\hline $\mathrm{C} 1$ & Rice straw $^{\mathrm{a}}+$ cattle dung ${ }^{\mathrm{b}}$ \\
\hline $\mathrm{C} 2$ & Rice straw + cattle dung $+5 \mathrm{~kg}$ from feldspar ore powder $(0.75 \%, \mathrm{w} / \mathrm{w})$ \\
\hline $\mathrm{C} 3$ & Rice straw + cattle dung $+5 \mathrm{~kg}$ from feldspar ore powder + Bacillus licheniformis \\
\hline $\mathrm{C} 4$ & Rice straw + cattle dung + isolate Bacillus licheniformis \\
\hline $\mathrm{C} 5$ & Rice straw + cattle dung $+5 \mathrm{~kg}$ from feldspar ore powder + Bacillus sonorensis \\
\hline C6 & Rice straw+cattle dung + Bacillus sonorensis \\
\hline $\mathrm{C} 7$ & $\begin{array}{l}\text { Rice straw }+ \text { cattle dung }+5 \mathrm{~kg} \text { from feldspar ore powder }+ \text { Mixture of Bacillus licheniformis and Bacillus } \\
\text { sonorensis }(1: 1)\end{array}$ \\
\hline $\mathrm{C} 8$ & Rice straw + cattle dung + Mixture of isolates Bacillus licheniformis and Bacillus sonorensis $(1: 1)$ \\
\hline
\end{tabular}

\section{Pot experiment}

Pot experiment was carried out to evaluate the effect of different composts to improve the vegetative growth of Wheat plant. Pots $(25 \mathrm{~cm}$ in diameter and $28 \mathrm{~cm}$ in high) were filled with $5 \mathrm{~kg}$ clay soil mixed with $50 \mathrm{~g} \mathrm{pot}^{-1}$ of compost. Physical, chemical and biological properties of soil used are showed in Table 3. A completely randomized design experiment comprised of 10 treatments (eight different composts and two control, one with chemical fertilizer $100 \% \mathrm{~N}$ and one without fertilizer), with nine replicates. Plants were collected and subjected to the following analyses at 30, 60 and 90 days after sowing: Plant height ( $\left.\mathrm{cm} \mathrm{plant}^{-1}\right)$, Fresh and dry weight ( $\mathrm{g}$ plant $^{-1}$ ), and $\mathrm{N} \%$ in root and shoot.

\section{Lyzemeter experiment}

Lyzemeter experiment was carried out during winter-growing season of 2016/2017 to evaluate the effect of different fertilizers (organic, inorganic, and biofertilizer) either separately or in mixture on the growth parameters and yield of wheat plants. Before preparation of soil, some physical, chemical and biological analysis of the experimental site $(0-30 \mathrm{~cm})$ were conducted and the results showed in Table 3. The experiment undertaken composed of 36 unit each of $80 \times 80$ $\mathrm{cm}$, and it was carried out as complete randomized block designed comprised 12 treatment, with 3 replicates for each treatment. Every unit of soil lyzemeter was prepared then mixed with compost No. 8 with different rates of $100,75,50$ and $25 \%$ as shown in Table 4 . This process mixed the compost fertilizer with the top $20 \mathrm{~cm}$ of soil lyzemeter that suitable for the root system of wheat plant.

Physical, chemical and biological properties were determined according to the standard methods reported by Black et al., (1965) and Jackson (1967), and Allen (1959), respectively.

Wheat grains were sown by broadcasting method at the rate of $7.2 \mathrm{~g} \mathrm{unit}^{-1}$ (recommended for wheat cultivation per hectare). For mineral treatments, different rates of Urea fertilizer (100, 75,50 and $25 \%$ ) were used and for biofertilizer treatment, wheat grains were mixed just before sowing with $30 \mathrm{~g}$ of sterilized carrier containing

Env. Biodiv. Soil Security Vol.2 (2018) 
TABLE 2. Chemical analysis of different composts used in the study

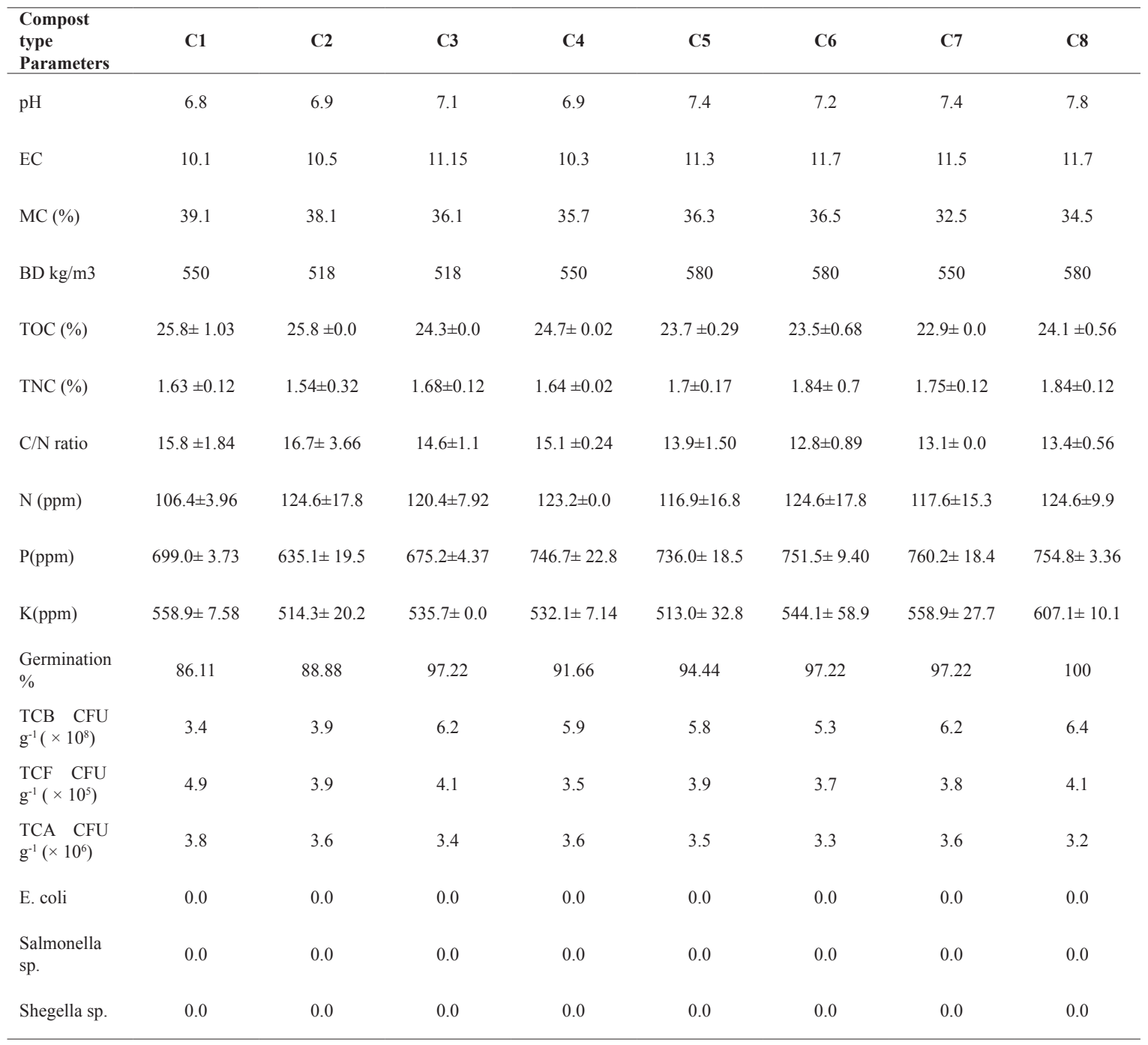

Source; Abdel-Rahman et al., 2016; TCB: Total Count of Bacteria; TCF: Total Count of Fungi; TCA: Total Count of Actinomycetes

$15 \mathrm{ml}$ of $10^{8} \mathrm{CFU} \mathrm{ml}^{-1}$ from $A$. chroococcum (SARS 10) strain using a sticking material. Water requirements and all cultural practices were applied according to the recommendations of Ministry of Agriculture and Land Reclamation.

\section{Experimental parameters}

Vegetative growth

At 60, 90 and 130 days after sowing, plants were collected and subjected to the following analyses: plant height $\left(\mathrm{cm} \mathrm{plant}^{-1}\right)$, fresh and dry weight $\left(\mathrm{g} \mathrm{plant}^{-1}\right)$, and flag leaf area $\left(\mathrm{cm}^{2}\right)$.

\section{Chemical constituents}

Nitrogen, phosphorus and potassium were determined in the dry matter of plant at different periods times 60, 90 and 130 days after sowing according to the methods described by Pregl Env. Biodiv. Soil Security Vol.2 (2018)
(1945), Trough and Mager (1939) and Browns and Lilliland (1946), respectively.

\section{Microbial estimations}

In the rhizosphere of soil samples, total count of bacteria was estimated by soil extract agar media according to Allen (1959), but the most probable number of $A$. chroococcum was estimated using modified Ashby's media according to AbdelMalek and Ishac (1968), and calculated using tables of Cochran (1950).

\section{Enzyme activity}

Dehydrogenase and urease activities in the soil samples were determined as described by Casida et al. (1964) and Pancholy and Rice (1973), respectively. 
TABLE 3. Some physical, chemical and biological properties of the pot and lyzemeters experimental soil

\begin{tabular}{|c|c|c|}
\hline \multirow{2}{*}{ Parameters } & \multicolumn{2}{|c|}{ Value } \\
\hline & Pot & lyzemeters \\
\hline \multicolumn{3}{|l|}{$\begin{array}{l}\text { Physical properties } \\
\text { Particle size distribution }\end{array}$} \\
\hline Clay $\%$ & 53.61 & 52.60 \\
\hline Silt \% & 21.93 & 23.10 \\
\hline Coarse sand $\%$ & 5.24 & 6.30 \\
\hline Fine sand $\%$ & 19.22 & 18.00 \\
\hline Texture grade & Clayey & Clayey \\
\hline \multicolumn{3}{|l|}{ Some chemical properties } \\
\hline $\mathrm{pH}(1: 2.5$ water suspension $)$ & 7.19 & 7.35 \\
\hline EC (ds.m-1 in soil paste) & 3.14 & 3.06 \\
\hline \multicolumn{3}{|l|}{ Soluble Cations (meq. $\mathrm{L}^{-1}$ ) } \\
\hline $\mathrm{Ca}^{++}$ & 3.94 & 4.18 \\
\hline $\mathrm{Mg}^{++}$ & 7.15 & 7.78 \\
\hline $\mathrm{Na}^{+}$ & 7.38 & 8.14 \\
\hline $\mathrm{K}^{+}$ & 0.18 & 0.22 \\
\hline \multicolumn{3}{|l|}{ Soluble Anions (meq. L ${ }^{-1}$ ) } \\
\hline $\mathrm{SO}_{4}^{--}$ & 9.32 & 10.27 \\
\hline $\mathrm{Cl}^{-}$ & 6.21 & 6.52 \\
\hline $\mathrm{HCO}_{3}^{-}$ & 3.12 & 3.53 \\
\hline $\mathrm{CO}_{3}^{--}$ & 0.0 & 0.0 \\
\hline \multicolumn{3}{|l|}{ Available macro element (ppm) } \\
\hline $\mathrm{N}$ & 35.21 & 34.70 \\
\hline $\mathrm{P}$ & 8.23 & 8.08 \\
\hline $\mathrm{K}$ & 210 & 200.7 \\
\hline \multicolumn{3}{|l|}{ Biological properties } \\
\hline Total count of bacteria & $159 \times 10^{7} \mathrm{CFU} \mathrm{g}^{-1}$ & $179 \times 10^{7} \mathrm{CFU} \mathrm{g}^{-1}$ \\
\hline Total count of fungi & $85 \times 10^{4} \mathrm{CFU} \mathrm{g}^{-1}$ & $66 \times 10^{4} \mathrm{CFU} \mathrm{g}^{-1}$ \\
\hline Total count of actinomycetes & $55 \times 10^{5} \mathrm{CFU} \mathrm{g}^{-1}$ & $71 \times 10^{5} \mathrm{CFU} \mathrm{g}^{-1}$ \\
\hline
\end{tabular}

Yield

Plants were harvested after 130 days from sowing, biological yield, grain yield and straw yield were estimated and transformed to ton per hectare (ton $\mathrm{ha}^{-1}$ ).

Statistical analysis

Data were analyzed by one-way analysis variances (ANOVA) using statistical software
SPSS 14.0 for windows. Duncan's multiple range test was used for comparison among the treatment means (Duncan 1955).

\section{Results and Discussion}

In this study, two experiments were conducted, the first experiment was carried out to evaluate the effect of different composting piles prepared by Abdel-Rahman et al., (2016) on the growth of wheat (Triticum aestivum L.) Cv. Misr 2. The second Env. Biodiv. Soil Security Vol.2 (2018) 

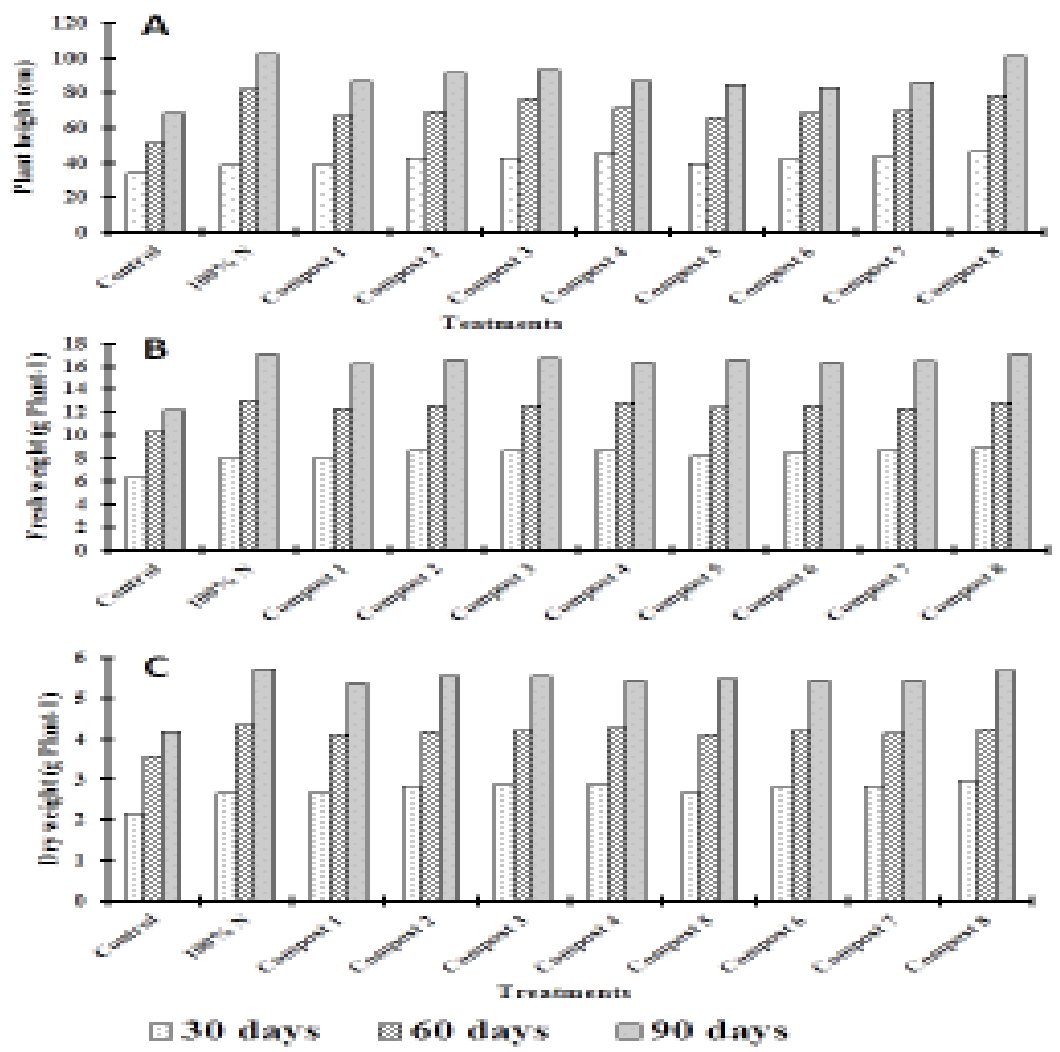

Fig. 1. Effect of different compost treaem and mineral fertilizer on whea plants beight

TABLE 4. Treatments used for lyzemeters experiment

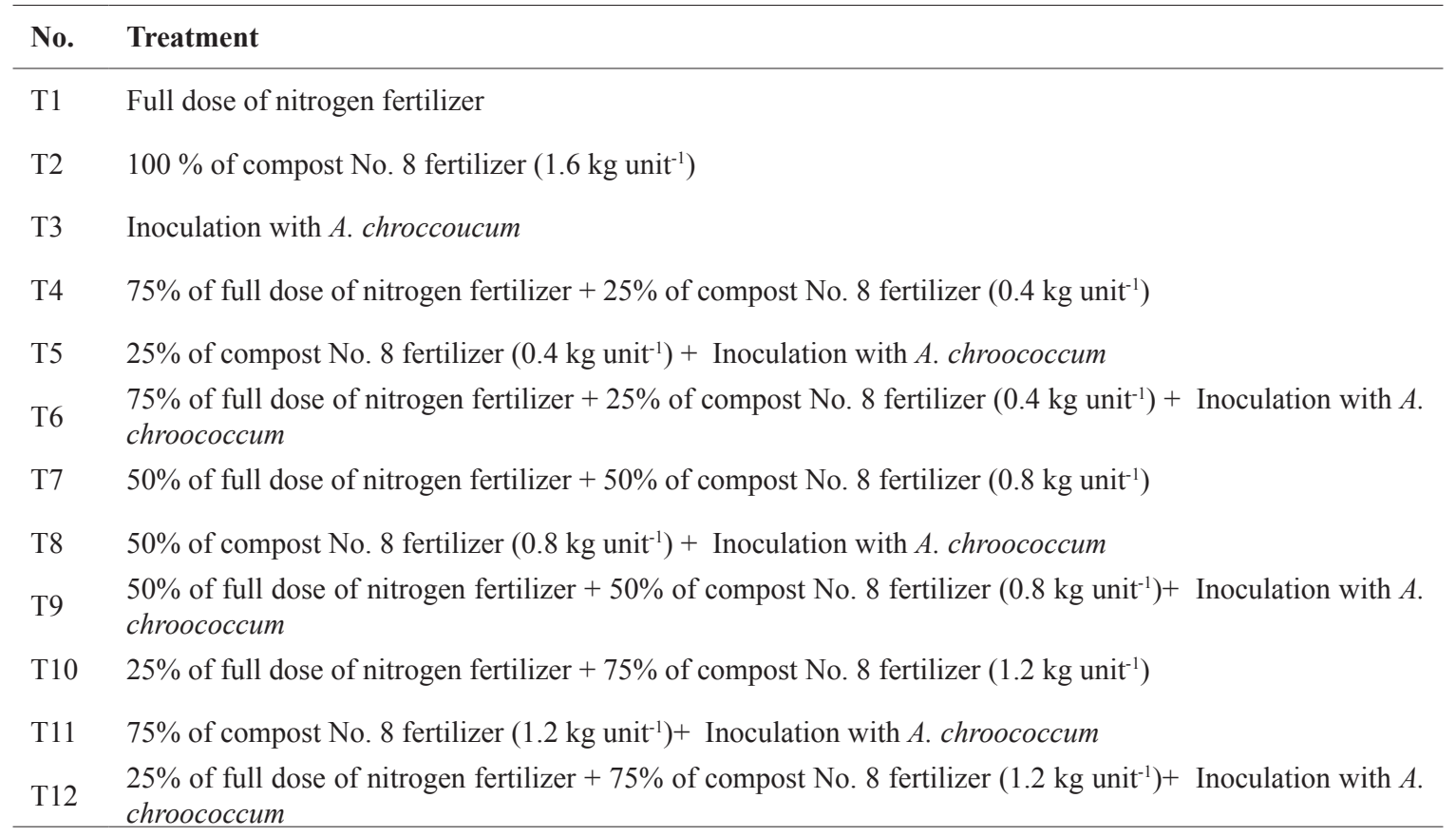

Env. Biodiv. Soil Security Vol.2 (2018) 
experiment was carried out at lyzemeters, where the best quality compost structure was selected and compared with the inoculation with nitrogen fixing bacteria A. chroococcum and applied with different rates of nitrogen fertilizer on wheat productivity.

\section{Pot experiment}

Effect of different composts on wheat growth

The effect of different compost treatments on the vegetative growth parameters (plant height [Fig. 1A], fresh weight [Fig. 1B], and dry weight [Fig. 1C] of wheat plants), at 30,60 and 90 days after sowing as compared to the control (one with recommended nitrogen fertilizer and one without fertilizer dose). The data showed that application of compost prepared using inoculation of cellulase-producing bacterial increase the wheat growth parameters (plant height, fresh and dry weight of wheat plants at 30 days after sowing) as compared to the control. Application of compost treatment No. 8 (produced by mixture of rice straw, cattle dung and inoculated with Bacillus licheniformis and Bacillus sonorensis) attained the highest vegetative growth parameters at $46.3 \mathrm{~cm}$ plant height, $8.92 \mathrm{~g}$ plant fresh weight and $2.96 \mathrm{~g}$ dry weight of wheat plants at 30 days after sowing comparing with control with increment by $19.9 \%$ and $11.15 \%$ for fresh and dry weight, respectively, comparing with control. These results are followed by compost treatment No. 4 (Rice straw + cattle dung + Bacillus licheniformis) and compost treatment No. 6 (Rice straw + cattle dung + Bacillus sonorensis). On the other hand, treatment with mineral nitrogen exhibited the best effect on the growth parameters at 60 and 90 days after sowing.

This result is in accordance with that obtained by Jamilu and Samina (2013) who found that the application of $4 \%$ parthenium green manure with EM increased shoot dry biomass of wheat. This is due to the ability of stimulating the mineralization of nutrients when the microorganisms are integrated with organic materials like compost (Fatunbi and Ncube 2009). Moreover, as the study site is drought prone area, the addition of compost to a soil increases the mean water holding capacity of a soil (Vengadaramana et al. 2012) and this could influence the production of wheat grains.

Effect of different composts on chemical analysis of wheat plants

Data presented in Table 5, revealed the effect of different compost treatments on the $\mathrm{N}$ content of shoot and root of wheat plants at 30, 60 and 90 days after sowing as compared to the control (recommended nitrogen fertilizers dose). At 30 days after sowing treatment with pile 8 treatment achieved the highest $\mathrm{N}_{2}(\%)$ in shoot and root content compared with control, while at 60 and 90 days after sowing treatment with mineral nitrogen exhibited the best effect on the same parameter.

This is due to the ability of stimulating the mineralization of nutrients when the microorganisms are integrated with organic materials like compost (Fatunbi and Ncube 2009). Moreover, addition of compost to a soil increases the mean water holding capacity of a soil (Vengadaramana et al. 2012) and this could influence the production of wheat grains. According to Govedarica et al. (2004) inoculation of wheat seed with diazotrophs increased the 1000 -seed weight from 2 to $14 \%$ under conditions of a greenhouse.

\section{Lyzemeter experiment growth parameters}

Data presented in Table 4 showed the 12 treatments used for conducting this experiment as indicated in "Material and Method" section either by using nitrogen fertilizer, compost, bio-fertilizer (Azotobacter chroococcum) separately or mixture of them at different ratio. The effect of different treatments on the vegetative growth parameters of wheat plants (plant height, flag leaf area $\left(\mathrm{cm}^{2}\right)$, fresh and dry weight $\left(\mathrm{g} \mathrm{plant}^{-1}\right)$ at 60,90 and 130 days after sowing) was recorded in Table 6.

In general, the co-inoculation treatments with compost, mineral $\mathrm{N}$ and $\mathrm{N}_{2}$-fixation microorganisms with different dose are more efficient than using each fertilizer alone or compared to traditional $\mathrm{N}_{2}$-fertilizer dose. The data showed that application of compost pile 8 and $\mathrm{N}_{2}$-fixing bacteria increased wheat growth parameters (plant height $(\mathrm{cm})$, flag leaf area $\left(\mathrm{cm}^{2}\right)$, fresh and dry weight $\left(\mathrm{g} \mathrm{plant}^{-1}\right)$ of wheat plants at 60, 90 and 130 days after sowing), as compared to the control. At 90 and 130 days of sowing effect of $\mathrm{N}_{2}$-fertilizer on growth parameters is more efficient than biological fixation alone. Treatment No. 9 (contained $50 \%$ of full dose of nitrogen fertilizer $+50 \%$ of full dose of compost (pile 8) + inoculation with biofertilizer (A. chroococcum) achieved the highest results at 60,90 and 130 days compared to other treatments. The inoculation of wheat with single $\mathrm{N}_{2}$ - fixers either alone or with compost gave less activity than the compound ones (El- Hamahmy et al. 2014). 
TABLE 5. Effect of different treatments on $N \%$ in root and shoot of wheat plants

\begin{tabular}{|c|c|c|c|c|c|c|}
\hline \multirow[t]{2}{*}{ Treatment } & \multicolumn{2}{|c|}{30 day } & \multicolumn{2}{|c|}{60 day } & \multicolumn{2}{|c|}{90 day } \\
\hline & Root & Shoot & Root & Shoot & Root & Shoot \\
\hline Control & $0.66 \mathrm{~d}$ & $1.34 \mathrm{f}$ & $0.70 \mathrm{f}$ & $1.36 \mathrm{f}$ & $0.75 \mathrm{~g}$ & $1.49 \mathrm{e}$ \\
\hline $100 \% \mathrm{~N}$ & $0.72 \mathrm{c}$ & $1.47 \mathrm{~d}$ & $0.91 \mathrm{a}$ & $1.80 \mathrm{a}$ & $0.99 \mathrm{a}$ & $1.99 \mathrm{a}$ \\
\hline Compost 1 & $0.66 \mathrm{~d}$ & $1.39 \mathrm{e}$ & $0.71 \mathrm{f}$ & $1.42 \mathrm{e}$ & $0.76 \mathrm{~g}$ & $1.51 \mathrm{e}$ \\
\hline Compost 2 & $0.80 \mathrm{a}$ & $1.57 \mathrm{bc}$ & $0.82 \mathrm{c}$ & $1.58 \mathrm{c}$ & $0.89 \mathrm{~d}$ & $1.74 \mathrm{~d}$ \\
\hline Compost 3 & $0.82 \mathrm{a}$ & $1.62 \mathrm{~b}$ & $0.87 \mathrm{~b}$ & $1.69 \mathrm{~b}$ & $0.93 \mathrm{c}$ & $1.82 \mathrm{c}$ \\
\hline Compost 4 & $0.81 \mathrm{a}$ & $1.62 \mathrm{~b}$ & $0.85 \mathrm{~b}$ & $1.67 \mathrm{~b}$ & $0.93 \mathrm{c}$ & $1.80 \mathrm{c}$ \\
\hline Compost 5 & $0.74 \mathrm{bc}$ & $1.48 \mathrm{~d}$ & $0.78 \mathrm{~d}$ & $1.52 \mathrm{~d}$ & $0.84 \mathrm{e}$ & $1.73 \mathrm{~d}$ \\
\hline Compost 6 & $0.76 b$ & $1.55 \mathrm{c}$ & $0.80 \mathrm{~d}$ & $1.58 \mathrm{c}$ & $0.84 \mathrm{e}$ & $1.75 \mathrm{~d}$ \\
\hline Compost 7 & $0.69 \mathrm{~d}$ & $1.46 \mathrm{~d}$ & $0.73 \mathrm{e}$ & $1.52 \mathrm{~d}$ & $0.80 \mathrm{f}$ & $1.72 \mathrm{~d}$ \\
\hline Compost 8 & $0.83 \mathrm{a}$ & $1.71 \mathrm{a}$ & $0.89 \mathrm{a}$ & $1.79 \mathrm{a}$ & $0.96 \mathrm{~b}$ & $1.95 \mathrm{~b}$ \\
\hline L.S.D. (0.05) & 0.03 & 0.04 & 0.02 & 0.02 & 0.02 & 0.03 \\
\hline
\end{tabular}

TABLE 6. Effect of organic, inorganic and biofertilizer treatments on wheat vegetative growth

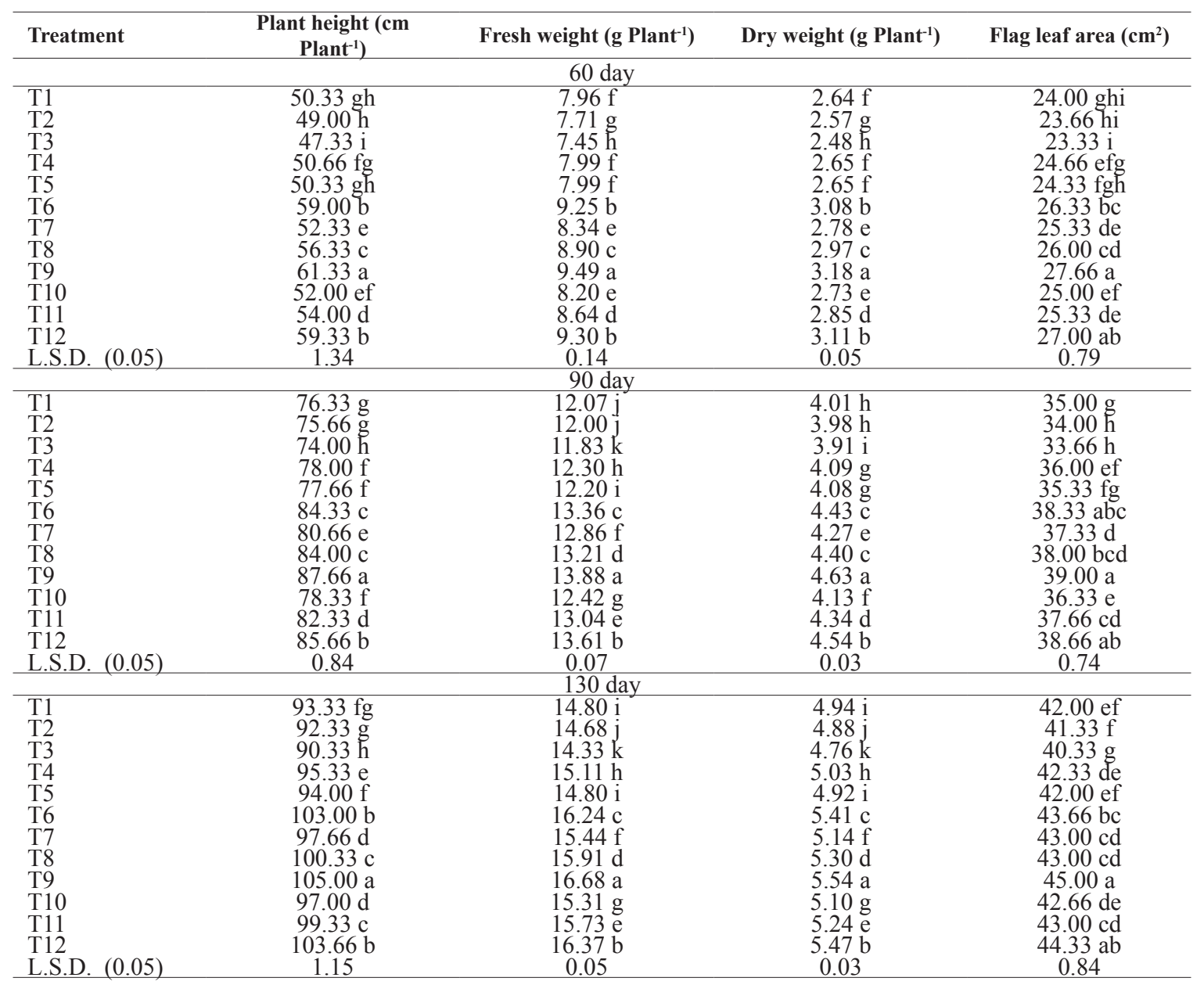

Env. Biodiv. Soil Security Vol.2 (2018) 


\section{Chemical parameters}

Results shown in Table 7, indicated the effect of different treatments on the minerals contents of wheat plants (NPK \%) at 60, 90, 130 days after sowing as compared to the control (recommended nitrogen fertilizers dose). In general, the coinoculation treatments with compost, mineral nitrogen and $\mathrm{N}_{2}$-Fixation microorganisms with different dose are more efficient than using each fertilizer separately. Interestingly, the highest NPK values were obtained using treatment No\# 9 that contained $50 \%$ of full dose of nitrogen fertilizer $+50 \%$ of full dose of compost (pile 8 ) fertilizer, plus inoculation with biofertilizer $(A$. chroococcum).

The increase in available nitrogen due to organic amendment application resulted in the greater multiplication of soil microbes, which caused and enhanced the conversion of organically bound $\mathrm{N}$ to inorganic forms. Therefore, litter addition might have resulted in marked improvement in the organic carbon and available $\mathrm{N}$ content in soil. The favorable soil condition under organic amendment might have helped in the mineralization of soil $\mathrm{N}$ leading to build up higher available N (Nour El-Din et al. 2017; Singh et al. 2017).

Combined application of fertilizers and manures increased available $\mathrm{K}$ content over control. The beneficial effect of organic amendments on available potassium may be described to the reduction of potassium fixation and release of potassium due to the interaction of organic matter with clay, the direct potassium addition to the potassium pool of the soil. Thus, it concluded the integrated nutrient management with organic manure, green manure, bio fertilizers and inorganic fertilizers enhances the productivity of wheat and fertility of soil. Organic manure enhanced the available $\mathrm{P}$ in soil through complexation of cations like $\mathrm{Ca}^{++}$and $\mathrm{Mg}^{++}$when it is applied in combination with inorganic fertilizer. Generally, addition of organic amendments with inorganic fertilizers had the beneficial effect in increasing the phosphate availability. (Nour El-Din et al. 2017; Singh et al. 2017).

To study the mechanism of productivity enhancement, microbial community (total bacterial count and total Azotobacter) in the soil was investigated for all treatments as shown in Table 8. As indicated in the table, treatment \# 9 exhibited the highest total microbial and
Azotobacter count among other treatments with a maximum value obtained after 90 days and decreased after that. The existence of Azotobacter microbes in different counts has improved growth and yield of cereal crops like wheat (Zahra et al. 2013).

Soil enzymes activities were also investigated as shown in Table 9. The highest dehydrogenase $\left(\mathrm{mg} \mathrm{TPF} \mathrm{g}^{-1}\right.$ soil d $\left.{ }^{-1}\right)$ and urease $\left(\mathrm{mg} \mathrm{NH}_{4}-\mathrm{N} \mathrm{g}^{-1}\right.$ soil $\left.\mathrm{d}^{-1}\right)$ activities were also obtained using treatment \# 9. Lower enzyme activities were obtained with other treatments. The activity of dehydrogenase reflects the oxidative capacity of the microbial biomass and it has been suggested as a good indicator of soil quality. The inoculation with beneficial microorganisms and organic matter represented in compost and its extracts helped in increasing the respiration and consequently increase in dehydrogenase enzyme (El- Hamahmy et al. 2014; Omara et al. 2017).

In addition, the effect of different treatments on biological yield (ton ha-1), grain yield (ton ha $\mathrm{ha}^{-1}$ ) and straw yield (ton ha ${ }^{-1}$ ) was shown in Table 10 in more efficient than using each one alone with compared to traditional $\mathrm{N}$-fertilizer dose with the highest data of 22.5, 8.64, and 13.92 ton ha ${ }^{-1}$, respectively with treatment $\# 9$.

Enriched compost along with 50\% of the recommended dose of nitrogen fertilizer significantly improved the plant height, no. of tillers pot $^{-1}$, no. of spikelets spike ${ }^{-1}$, straw and grain yield. Our findings were in line with the results of a field experiment conducted to evaluate the influence of compost fertilizer mixed with chemical fertilizer on growth and yield of wheat agree with (Akhtar 2007)

The analysis of variance of the yield showed that statistically significant differences existed for all major sources of variation and all interactions. The application of microorganisms increased the availability of nutrients, which had a positive impact on yield parameters (Milosevic et al. 2008). The enhancing effect of seed inoculation with $\mathrm{N}_{2}$ fixing bacteria on the growth and yield of wheat was reported by many researchers (Bhattarai and Hess 1993; Ozturk et al. 2003). This improvement may be attributed to the high nitrogen uptake by the inoculated plants and the ability of bacterial strains to produce growth promoting substances (Haahtela et al. 1988). 
TABLE 7. Effect of organic, inorganic and biofertilizer treatments on NPK \% of wheat plants

\begin{tabular}{lccccccccc}
\hline \multirow{2}{*}{ Treatment } & \multicolumn{3}{c}{$\begin{array}{c}\text { N (\%) } \\
\text { Days }\end{array}$} & \multicolumn{3}{c}{ P (\%) } \\
& \multicolumn{3}{c}{ Days } & \multicolumn{3}{c}{$\begin{array}{c}\text { K (\%) } \\
\text { Days }\end{array}$} \\
\cline { 2 - 10 } T1 & 90 & 130 & 60 & 90 & 130 & 60 & 90 & 130 \\
T2 & $2.05 \mathrm{~g}$ & $2.19 \mathrm{j}$ & $2.30 \mathrm{i}$ & $0.068 \mathrm{i}$ & $0.078 \mathrm{i}$ & $0.093 \mathrm{i}$ & $2.77 \mathrm{~g}$ & $2.81 \mathrm{~g}$ & $2.08 \mathrm{i}$ \\
T3 & $1.99 \mathrm{~h}$ & $2.11 \mathrm{j}$ & $2.24 \mathrm{j}$ & $0.067 \mathrm{i}$ & $0.075 \mathrm{j}$ & $0.090 \mathrm{j}$ & $2.72 \mathrm{~h}$ & $2.79 \mathrm{~h}$ & $2.05 \mathrm{j}$ \\
T4 & $1.97 \mathrm{~h}$ & $2.09 \mathrm{j}$ & $2.19 \mathrm{k}$ & $0.066 \mathrm{j}$ & $0.073 \mathrm{k}$ & $0.087 \mathrm{k}$ & $2.69 \mathrm{i}$ & $2.77 \mathrm{~h}$ & $2.01 \mathrm{k}$ \\
T5 & $2.12 \mathrm{e}$ & $2.31 \mathrm{~g}$ & $2.41 \mathrm{~h}$ & $0.071 \mathrm{~h}$ & $0.083 \mathrm{~g}$ & $0.098 \mathrm{~g}$ & $2.80 \mathrm{f}$ & $2.85 \mathrm{f}$ & $2.17 \mathrm{~g}$ \\
T6 & $2.09 \mathrm{f}$ & $2.28 \mathrm{~h}$ & $2.40 \mathrm{~h}$ & $0.070 \mathrm{~h}$ & $0.081 \mathrm{~h}$ & $0.095 \mathrm{~h}$ & $2.77 \mathrm{~g}$ & $2.84 \mathrm{f}$ & $2.15 \mathrm{~h}$ \\
T7 & $2.34 \mathrm{~b}$ & $2.48 \mathrm{c}$ & $2.63 \mathrm{c}$ & $0.084 \mathrm{c}$ & $0.096 \mathrm{~b}$ & $0.107 \mathrm{c}$ & $2.91 \mathrm{bc}$ & $3.04 \mathrm{a}$ & $2.36 \mathrm{c}$ \\
T8 & $2.28 \mathrm{~d}$ & $2.39 \mathrm{e}$ & $2.51 \mathrm{f}$ & $0.077 \mathrm{f}$ & $0.089 \mathrm{e}$ & $0.102 \mathrm{e}$ & $2.83 \mathrm{e}$ & $2.94 \mathrm{~d}$ & $2.24 \mathrm{f}$ \\
T9 & $2.31 \mathrm{c}$ & $2.44 \mathrm{~d}$ & $2.60 \mathrm{~d}$ & $0.082 \mathrm{~d}$ & $0.093 \mathrm{c}$ & $0.105 \mathrm{~d}$ & $2.90 \mathrm{c}$ & $3.01 \mathrm{~b}$ & $2.32 \mathrm{~d}$ \\
T10 & $2.38 \mathrm{a}$ & $2.54 \mathrm{a}$ & $2.69 \mathrm{a}$ & $0.090 \mathrm{a}$ & $0.098 \mathrm{a}$ & $0.111 \mathrm{a}$ & $2.95 \mathrm{a}$ & $3.05 \mathrm{a}$ & $2.45 \mathrm{a}$ \\
T11 & $2.27 \mathrm{~d}$ & $2.36 \mathrm{f}$ & $2.45 \mathrm{~g}$ & $0.073 \mathrm{~g}$ & $0.086 \mathrm{f}$ & $0.101 \mathrm{f}$ & $2.82 \mathrm{e}$ & $2.90 \mathrm{e}$ & $2.19 \mathrm{~g}$ \\
T12 & $2.29 \mathrm{~d}$ & $2.42 \mathrm{~d}$ & $2.56 \mathrm{e}$ & $0.080 \mathrm{e}$ & $0.092 \mathrm{~d}$ & $0.104 \mathrm{~d}$ & $2.87 \mathrm{~d}$ & $2.96 \mathrm{c}$ & $2.27 \mathrm{e}$ \\
L.S.D. (0.05) & $2.36 \mathrm{~b}$ & $2.51 \mathrm{~b}$ & $2.65 \mathrm{~b}$ & $0.087 \mathrm{~b}$ & $0.097 \mathrm{a}$ & $0.108 \mathrm{~b}$ & $2.92 \mathrm{~b}$ & $3.04 \mathrm{a}$ & $2.39 \mathrm{~b}$ \\
\hline
\end{tabular}

TABLE 8. Influence of organic, inorganic and biofertilizer treatments on Log number of total bacterial count and Azotobacter count (CFU $\mathrm{g}^{-1}$ ) of soil at different time of sowing

\begin{tabular}{|c|c|c|c|c|c|c|}
\hline \multirow{2}{*}{ Treatment } & \multicolumn{3}{|c|}{$\begin{array}{c}\text { Total count of bacteria } \mathrm{CFU} \mathrm{\textrm {g } ^ { - 1 }} \\
\text { Days }\end{array}$} & \multicolumn{3}{|c|}{ 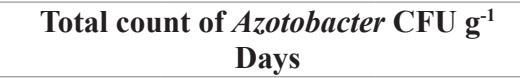 } \\
\hline & 60 & 90 & 130 & 60 & 90 & 130 \\
\hline T1 & $5.26 \mathrm{~g}$ & $6.80 \mathrm{f}$ & $4.70 \mathrm{~g}$ & $3.13 \mathrm{c}$ & $4.56 \mathrm{~g}$ & $2.36 \mathrm{~d}$ \\
\hline $\mathrm{T} 2$ & $5.66 \mathrm{de}$ & $7.43 \mathrm{c}$ & $5.23 \mathrm{de}$ & $3.40 \mathrm{~b}$ & $5.10 \mathrm{e}$ & $2.70 \mathrm{c}$ \\
\hline $\mathrm{T} 3$ & $5.50 \mathrm{f}$ & $7.03 \mathrm{e}$ & 5.10 ef & $3.33 \mathrm{~b}$ & $4.83 \mathrm{f}$ & $2.66 \mathrm{c}$ \\
\hline $\mathrm{T} 4$ & $5.56 \mathrm{ef}$ & $7.23 \mathrm{~d}$ & $5.23 \mathrm{de}$ & $3.40 \mathrm{~b}$ & $5.13 \mathrm{de}$ & $2.73 \mathrm{c}$ \\
\hline $\mathrm{T} 5$ & $5.50 \mathrm{f}$ & $7.03 \mathrm{e}$ & $5.06 \mathrm{f}$ & $3.40 \mathrm{~b}$ & $4.90 \mathrm{f}$ & $2.63 \mathrm{c}$ \\
\hline T6 & $6.03 \mathrm{~b}$ & $7.70 \mathrm{ab}$ & $5.63 \mathrm{~b}$ & $3.80 \mathrm{a}$ & $5.66 \mathrm{ab}$ & $2.96 \mathrm{~b}$ \\
\hline $\mathrm{T} 7$ & $5.66 \mathrm{de}$ & $7.46 \mathrm{c}$ & $5.26 \mathrm{~cd}$ & $3.33 \mathrm{~b}$ & $5.36 \mathrm{c}$ & $2.63 \mathrm{c}$ \\
\hline $\mathrm{T} 8$ & $5.80 \mathrm{c}$ & $7.60 \mathrm{~b}$ & $5.40 \mathrm{c}$ & $3.46 \mathrm{~b}$ & $5.60 \mathrm{~b}$ & $2.73 \mathrm{c}$ \\
\hline T9 & $6.16 \mathrm{a}$ & $7.80 \mathrm{a}$ & $5.83 \mathrm{a}$ & $3.86 \mathrm{a}$ & $5.76 \mathrm{a}$ & $3.16 \mathrm{a}$ \\
\hline $\mathrm{T} 10$ & $5.60 \mathrm{ef}$ & $7.36 \mathrm{c}$ & $5.16 \mathrm{def}$ & $3.46 \mathrm{~b}$ & $5.23 \mathrm{~d}$ & $2.66 \mathrm{c}$ \\
\hline $\mathrm{T} 11$ & $5.73 \mathrm{~cd}$ & $7.60 \mathrm{~b}$ & $5.30 \mathrm{~cd}$ & $3.46 \mathrm{~b}$ & $5.63 \mathrm{~b}$ & $2.63 \mathrm{c}$ \\
\hline $\mathrm{T} 12$ & $6.10 \mathrm{ab}$ & $7.76 \mathrm{a}$ & $5.76 \mathrm{ab}$ & $3.76 \mathrm{a}$ & $5.66 \mathrm{ab}$ & $2.93 \mathrm{~b}$ \\
\hline L.S.D. $(0.05)$ & 0.12 & 0.10 & 0.14 & 0.13 & 0.12 & 0.12 \\
\hline
\end{tabular}

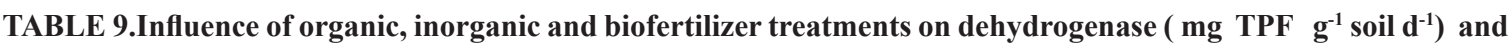
urease (mg NH4-N gil ${ }^{-1}$ soil d-1) activities at different time of sowing

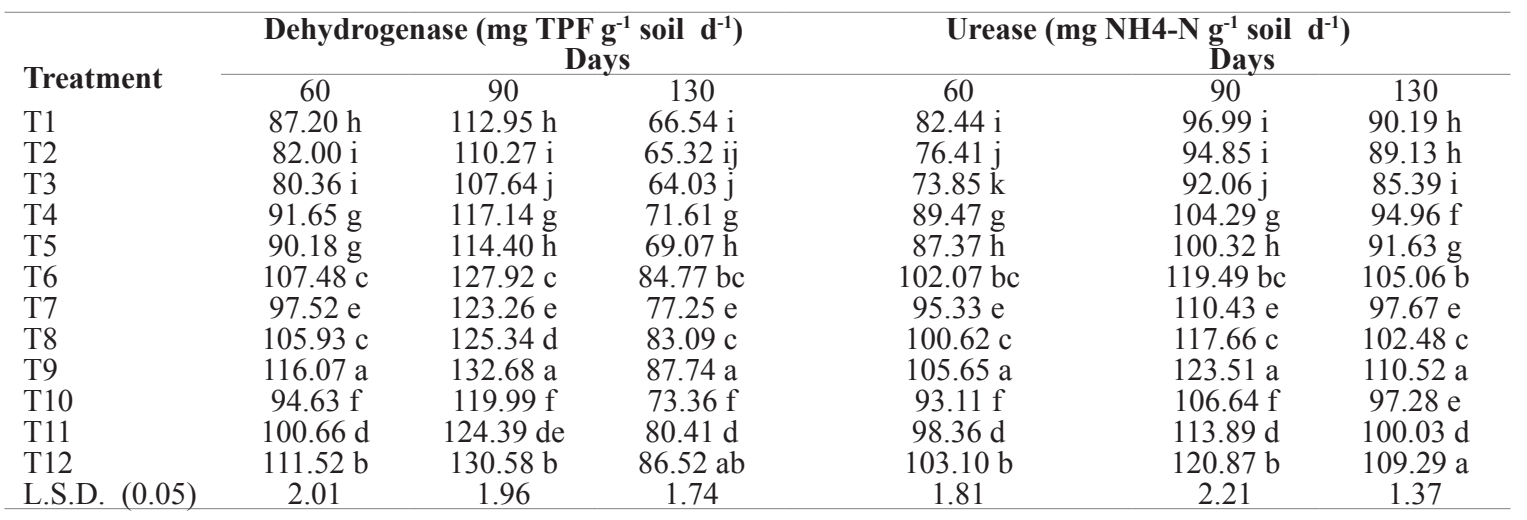

Env. Biodiv. Soil Security Vol.2 (2018) 
TABLE 10. Effect of organic, inorganic and biofertilizer treatments on biological yield, grain yield and straw yield of wheat plant

\begin{tabular}{|c|c|c|c|}
\hline Treatment & $\begin{array}{l}\text { Biological yield } \\
\quad\left(\text { ton } \mathrm{ha}^{-1}\right)\end{array}$ & $\begin{array}{l}\text { Grain yield } \\
\left.\text { (ton } \text { ha }^{-1}\right)\end{array}$ & $\begin{array}{c}\text { Straw yield } \\
\left(\text { ton } \mathrm{ha}^{-1}\right)\end{array}$ \\
\hline $\mathrm{T} 1$ & $21.39 \mathrm{j}$ & $8.09 \mathrm{~h}$ & $13.30 \mathrm{j}$ \\
\hline $\mathrm{T} 2$ & $21.30 \mathrm{k}$ & $8.05 \mathrm{i}$ & $13.25 \mathrm{k}$ \\
\hline $\mathrm{T} 3$ & 21.131 & $7.96 \mathrm{j}$ & 13.161 \\
\hline $\mathrm{T} 4$ & $21.57 \mathrm{~h}$ & $8.15 \mathrm{~g}$ & $13.42 \mathrm{~h}$ \\
\hline T5 & $21.46 \mathrm{i}$ & $8.10 \mathrm{~h}$ & $13.35 \mathrm{i}$ \\
\hline $\mathrm{T} 6$ & $22.33 \mathrm{c}$ & $8.52 \mathrm{~b}$ & $13.80 \mathrm{c}$ \\
\hline $\mathrm{T} 7$ & $21.90 \mathrm{f}$ & $8.30 \mathrm{e}$ & $13.59 \mathrm{f}$ \\
\hline $\mathrm{T} 8$ & $22.17 \mathrm{~d}$ & $8.44 \mathrm{c}$ & $13.73 \mathrm{~d}$ \\
\hline T9 & $22.57 \mathrm{a}$ & $8.64 \mathrm{a}$ & $13.92 \mathrm{a}$ \\
\hline $\mathrm{T} 10$ & $21.76 \mathrm{~g}$ & $8.24 \mathrm{f}$ & $13.52 \mathrm{~g}$ \\
\hline $\mathrm{T} 11$ & $22.03 \mathrm{e}$ & $8.37 \mathrm{~d}$ & $13.66 \mathrm{e}$ \\
\hline $\mathrm{T} 12$ & $22.49 \mathrm{~b}$ & $8.62 \mathrm{a}$ & $13.86 \mathrm{~b}$ \\
\hline L.S.D. $(0.05)$ & 0.05 & 0.03 & 0.03 \\
\hline
\end{tabular}

Barik and Goswami (2003), reported that grains inoculation with $A$. chroococcum strains significantly influenced the growth and yield of wheat. These strains have the ability to produce vitamins like thiamine and riboflavin and plant hormones viz., indole acetic acid, gibberellins and cytokinins. For example, IAA production by Azotobacter sp. strains lead to vigorous root growth resulting in more surface area and thus enabling access to more nutrients in the soil (Singh et al. 2013).

The superior effect resulted from the treatment No. 9 on increasing plants' vegetative growth as well as value for all flowering and yield parameters may be due to attributed the beneficial microorganisms with $50 \% \mathrm{NPK}+$ compost that break down and release minerals from organic manure treatments and uptake by plants (Weaam, 2017).

\section{Conclusion}

In this study, the effect of different fertilizers on the growth and yield of wheat (Triticum aestivum L.) Cv. Misr 2 were compared and evaluated. Different organic fertilizers were compared, and the pile No.8 exhibited the best effect on the wheat plant in pot experiment. This compost was mixed with inorganic and biofertilizer at different ratio and examined in lyzemeters experiment.
Use of $50 \%$ of full dose of compost supplemented with $50 \%$ nitrogen fertilizer and A. chroococcum exhibited the highest effect on wheat growth, yield as well as enzymatic activities (dehydrogenase and urease) in soil compared to other treatments.

So, this approach may also improve soil health, reduce dependence on chemical fertilizer and most likely be helpful in reducing huge piles of organic waste, thus cleaning our environment.

\section{Acknowledgment}

Thanks to all staff members and colleagues in The Bacteriology Research Laboratory, Sakha Agricultural Research Station, Kafr El-Sheikh, Egypt for their valuable cooperation which made completion of this work possible

\section{References}

Abdelhady S, Borello D, Shaban A, Rispoli F (2014) Viability study of biomass power plant fried with rice straw in Egypt. Energy Proced. 61, 211-215.

Abdel-Malek Y and Ishac YZ (1968) Evaluation of methods used in counting Azotobacter. J. Appl. Bacterial., 31: 257-267.

Abdel-Rahman MA, Abdel-Shakour EH, Nour Eldin M, Refaat MA, Ewais EA and Alrefaey HMA (2015) A novel promising thermotolerant cellulaseproducing Bacillus licheniformis 1-1v strain

Env. Biodiv. Soil Security Vol.2 (2018) 
suitable for composting of rice straw. Int. J. Adv. Res. 3 (12), 413-423.

Abdel-Rahman MA, El-Din MN, Refaat BM, Abdel-Shakour EH, Ewais EED, Alrefaey HM (2016) Biotechnological application of thermotolerant cellulose-decomposing bacteria in composting of rice straw. Annals Agricultural Sci. 61 (1) 135-143.

Abdel-Rahman MA, Tashiro Y and Sonomoto K (2011) Lactic acid production from lignocellulose-derived sugars using lactic acid bacteria: overview and limits. J. Biotechnol. 156, 286-301.

Akhtar, M.J., Asghar, H.N., Asif, M. and Zahir, Z.A. (2007) Growth and yield of wheat as affected by compost enriched with chemical fertilizer, L-tryptophan and rhizobacteria. Pak. J. Agri. Sci., Vol. 44 (1).

Allen ON (1959) Experiments in soil Bacteriology University of Wiscosin second printing. 202.

Bandhu RB and Parbati A (2013) Effect of Azotobacter On Growth and Yield of Maize. SAARC Journal Agriculture. 11 (2): 141-147.

Barik AK and Goswami A (2003) Efficacy of biofertilizers with nitrogen levels on growth, productivity and economics in wheat (Triticum aestivum). Indian Journal of Agronomy. 48 (2):100102.

Bhattarai T and Hess D (1993) Yield responses of Nepalese spring wheat (Triticum aestivum L.) cultivars to inoculation with Azospirillum spp. of Nepalese origin. Plant Soil, 151: 67-76.

Brown JD and Lilliland O (1946) Rapid determination of potassium and sodium in plant material and soils extracts by flam-photometry. Proc. Amer. Soc. Hort. Sci., 48: 341-346.

Casida LE, Klein DA and Snatoro T (1964) Soil dehydrogenase activity. Soil Sci., 98, 371-376.

Cochran DS (1950) Estimation of bacteria densities by means of the most probable number. Biometrics, 6:105.

Cooperband L and Wisconsin M (2002) Building Soil Organic Matter with Organic Amendments. Center for Integrated Agricultural Systems (CIAS), College of Agricultural and Life Sciences, University of Wisconsin-Madison.

Dehghani I, Kordlaghari K and Mohamadinia G (2013) Effect of effective microorganisms activate (EMa) on growth, yield and yield. Annals Biol. Res. 4 (4): 126-129.

Duncan DB (1995) Multiple ranges and multiple F tests. Biometrics.11: 1-42.

Env. Biodiv. Soil Security Vol.2 (2018)
El- Hamahmy AF, Ghanem KH, Massoud ON, Hassn EA and Shoeip AMO (2014) Improving the Productivity of Wheat (Triticum aesitivum L.) Cultivated under Saline Soil Using Some N2Fixers Halophillic Bacteria and Compost. Middle East Journal of Agriculture Research, 3 (4): 827 837, 2014 ISSN 2077-4605.

Fatunbi AO and Ncube L (2009) Activities of Effective Microorganism (EM) on the Nutrient Dynamics of Different Organic Materials Applied to Soil. AmEuras. J. Agron., 2(1): 26-35.

Gebrejewergs A and Daniel B (2016) The Effect of Compost Use with Effective Micro-Organisms (EM) On Grain and Biomass Yield of Wheat Cultivated In Tigray, Ethiopia. Natural Resource Management Directorate, Tigray Agricultural Research Institute, Mekelle, P.O.Box: 492, Ethiopia

Govedarica M, Jeličić Z, Jarak M, Milošević N, Kuzevski J and Krstanović S (2004) Azotobacter chroococcum as alternative to conventional fertilization in the production of maize. Zemljište I biljka, 55 (3): 217-222,

Haahtela K, Tuula T, Nurmiaho-lassila E and Korhonen TK (1998) Effects of inoculation of Poa pratensis and Triticum aestivum with root-associated, $\mathrm{N}_{2}$ fixing Klebsiella, Enterobacter and Azospirillum. Plant Soil, 106: 239-248,

Jamilu T and Samina F (2013) Growth and yield reaction of wheat to Effective Microorganisms and parthenium green manure. Int. J. Manures Fertilizers 2(5): 315-322.

Jensen HL (1951) Notes on the biology of Azotobacter. Proc. Soc. Appl. Bacteriol.,14: 89-103.

Jiang T, Li G, Tang Q, Ma X, Wang G and Schuchardt F (2015) Effects of aeration method and aeration rate on greenhouse gas emissions during composting of pig feces in pilot scale. J. Environ. Sci. 31, 124-132

Jimenez DJ, Jose SM and Maria MM (2011) Characterization of free nitrogen fixing bacteria of the genus Azotobacter in organic vegetable-grown colombian soils. Brazilian Journal of Microbiology. 42: 846-858.

Jusoh ML, Manaf LA, Latiff PA (2013) Composting of rice straw with effective microorganisms (EM) and its influence on compost quality. Iranian J. Envi. Health Sci. Eng., 10 (17): 1-9.

Kausar H, Ismail MR, Saud HM, Habib SH, Othman $\mathrm{R}$ and Bhuiyan MSH (2014) Changes of physical and chemical characteristics during microbial composting of rice straw at various $\mathrm{Ph}$ levels. Compos. Sci. Utiliz. 22, 153-163. 
Khosro M and Yousef S (2012) Bacterial Biofertilizers for Sustainable Crop Production: A Review. ARPN Journal of Agricultural and Biological Science, 7(5); 307-316.

Kloepper JW (1994) Plant growth promoting bacteria (other systems). 'In: Azospirillum/Plant Association' (ed. J. Okon). 'Boca Raton, FL: CRC Press. 137-154.

Lakshminarayana KR, Shukla B, Sindhu SS, Kumari P, Narula N and Sheoran RK (2000) Analogue resistant mutants of Azotobacter chroococcum derepressed for nitrogenase activity and early ammonia excretion having potential as inoculants for cereal crops. Indian J. Experimental Biology, 38: $373-378$.

Lindani N and Brutsch M (2012) Effects of the integrated use of effective micro-organisms, compost and mineral fertilizer on greenhousegrown tomato. Afr. J. Plant Sci., 6 (3): 120-124.

Liu D, Zhang R, Wu H, Xu D, Tang Z, Yu G, Xu Z and Shen, Q (2011) Changes in biochemical and microbiological parameters during the period of rapid composting of dairy manure with rice chaff. Bioresour. Technol. 102, 9040-9049.

Mariangela D and Francesco M (2010) Long-term effects of organic amendments on soil fertility. A review. Agron. Sustain. Dev., 30: 401-422.

Milošević N, Tintor B and Cvijanović G (2008) Effect of inoculation with Azotobacter chroococcum on wheat yield and seed quality. International Conference: Conventional and molecular breeding of field and vegetable crops, Novi Sad, Serbia: 4, elektronski,

Mishra DJ, Singh R, Mishra UK and Shahi SK (2013) Role of Bio-Fertilizer in Organic Agriculture: A Review. Research J. Recent Sciences. 2: 39-41.

Namvar A, Khandan T and Shojaei M (2012) Effects of bio and chemical nitrogen fertilizer on grain and oil yield of sunflower (Helianthus annuus L.) under different rates of plant density. Annals of Biological Research. 3(2): 1125-1131.

Ndona, R.K., Friedel, J.K., Spornberger, A., Rinnofner, T. and Jezik, K. (2011) 'Effective Micro-organisms' (EM): An effective plant strengthening Agent for Tomatoes in Protected Cultivation. Biol. Agric. Hort., 27: 189- 204.

Nour El-Din M, Omara A and Elbagory MH (2017) Effect of Bulking Agent Levels (Rice Straw) on Compost Quality and Net Return. Inter. J. Plant \& Soil Sci., 19 (3): 1-12.
Omara A, Hauka F, Aida A, Nour El-Din M and Kassem M (2017) The Role of Some PGPR Strains to Biocontrol Rhizoctonia Solani in Soybean and Enhancement the Growth Dynamics and Seed Yield. Environ. Biodiversi. \& Soil Security, 1: 47 -59 .

Ozturk A, Caglar O and Sahin F (2003) Yield response of wheat and barley to inoculation of plant growth promoting rhizobacteria at various levels of nitrogen fertilization. J. Plant Nutr. Soil Sci, 166: 262-266,

Pancholy SK and Rice EL (1973) Soil enzymes in relation to old succession: Amylase, invertase, cellulose, dehydrogenase and urease. Soil. Sci. Soc. American Proc., 37, 47-50.

Peoples MB, Herridge DF and Ladha J.K. (1995) Biological nitrogen fixation: an efficient source of nitrogen for sustainable agricultural production. Plant Soil. 174:3-28.

Pregl F (1945) Quantitative Organic Microanalysis $4^{\text {th }}$ Edit. J. A. Churchill Ltd. London.

Qian X, Shen G, Wang Z, Guo C, Liu Y, Lei Z and Zhang Z (2014) Co-composting of livestock manure with rice straw: Characterization and establishment of maturity evaluation system. Waste Manag. 34, $530-535$

Rana, A., Joshi, M., Prasanna, R., Shivay, Y.S. and Nain, L. (2012) Biofortification of wheat through inoculation of plant growth promoting rhizobacteria and cyanobacteria. European J. Soil. Biology. 50: $118-126$.

Sakdaronnarong, C. and Jonglertjunya, W. (2012) Rice straw and sugarcane bagasse degradation mimicking lignocellulose decay in nature: an alternative approach to biorefinery. Science Asia 38, 364-372.

Singh NK, Chaudhary FK and Patel DB (2013) Effectiveness of Azotobacter bioinoculant for wheat grown under dryland condition. J Environ Biol 34: 927-932

Singh, pp., Rashmi, P. and Meena, R. (2017) Response of integrated nutrient management on yield and chemical properties of soil under rice Wheat Cropping system. Inter. J. Chemical Studies; 5 (2): 366-369.

Trough, E. and Mager, A.H. (1939) Improvement in deiness colorimetric method for phosphorus and arsenic. Ind. En. Chemical Anal. Ed., 1:136-139.

Tsai, S.H., Liu, C.P. and Yang, S.S. (2007) Microbial 
conversion of food wastes for biofertilizer production with thermophilic lipolytic microbes. Renewable Energy. 32 (6), 904-915.

Vengadaramana, A. and Jashothan, P.T.J. ( 2012) Effect of organic fertilizers on the water holding capacity of soil in different terrains of Jaffna peninsula in Sri Lanka. J. Nat. Prod. Plant Resour., 2 (4): 500-503.
Weaam, R.A.S. (2017) Chemical and Biological Fertilization of Calendula officinalis Plant Grown in Sandy Soil. J. Horticultural. Sci., Ornamental Plants 9 (1): 17-27.

Zahra, S., Hemmatollah, P. and Ayoub, H. (2013) Plant growth promoting rhizobacteria effects on yield and yield components of four rapeseed (Brassica napus L.) cultivars under salt condition. Inter. J. Agric. Crop Sci., 1869- 1873.

(Received 8/4/2018

accepted $1 / 5 / 2018$ ) 